\title{
POMAHCbKI MOBИ
}

УДК 811.133.1'42

DOI https://doi.org/10.32838/2663-6069/2020.1-1/33

Буць Ж. В.

Київський національний лінгвістичний університет

\section{МАНІПУЛЯТИВНИЙ ПОТЕНЦІАЛ КОМПОЗИЦІЙНОї СТРУКТУРИ ХУДОЖНЬОГО НАРАТИВУ М. ЛЕВІ (НА МАTЕРIAЛI РОМАНУ «VOUS REVOIR»)}

У статті проаналізовано наративний простір роману сучасного франиузького письменника M. Леві «Vous revoir». Зокрема, особлива увага приділена композиіийній будові твору та визначенню ї̈ маніпулятивного потениіалу. Автор роботи, трунтуючись на ідеях сучасних лінгвістів, намагається поєднати різноманітні напрями мовознавства. Передусім у тексті надається пояснення розумінню маніпуляиії автором та обтрунтовується поєднання декількох лінгвістичних парадигм в одному дослідженні.

У запропонованій роботі описано основні ракурси вчень з художнього наративу. На засадах сучасної наратології пояснюється та формулюється ідея реалізації маніпуляиії в художньому просторі сучасної франиузької романістики мовними і мовленнєвими засобами. Задля розуміння маніпулятивного впливу, здійсненого в наративному просторі франиузького письменника, увага сфокусована на наративній формі автора. Доведено, що літератор прагне до наративної форми гетеродієгетичного типу в екстрадієгетичній ситуаиії. Тобто в досліджуваних романах письменника наратор, що розповідає історії, знаходиться поза межами оповіді, а фокус зосереджується на головних персонажсах відповідних подій.

Особлива увага авторки статті зосереджена на композииійній будові роману Марка Леві "Vous revoir». Дотримуючись тектоніки аналізованого роману, описано основні композиційні складники твору М. Леві та охарактеризовано їхні маніпулятивні функиії. У результаті проведеного дослідження доведено, що композиџійна будова роману «Vои revoir» не лише структурує наративний простір, а й набуває маніпулятивного потенціалу, оскільки спрямовує читача на розуміння подій у тому чи іншому ракурсі, иікавить його, змушує дізнатися кінець історії.

Узагальнюючи висновки проведеної роботи, окреслено перспективи подальших пошуків з ичієї теми. Отже, автор вважає доцільним звернутися до гендерної диференціачії наративних типів та простежити композиційні особливості французького наративного простору з боку прояву його маніпулятивного потенціалу.

Ключові слова: наратив, композиція, маніпуляція, маніпулятивний вплив, маніпулятивний потенціал, художній простір.

Постановка проблеми. Останнім часом сучасна романістика взагалі та романська зокрема постають одним 3 основних об'єктів лінгвістичних вчень. Наразі активно виокремлюються дослідження наративного художнього простору (I. М. Горбач, Є. О. Дегтярьова, В. В. Дуркевич, О. В. Рибаль, М. І. Руденко, Р. І. Савчук та ін.), що надає можливість зануритися в художню тканину й осягнути спосіб існування літературного твору.

Розуміючи маніпуляцію як прихований вплив на свідомість за допомогою сформованих когнітивних образів світу [4, с. 38], художній твір виявляється площиною реалізації маніпуляції, оскільки читач сприймає художній світ відповідно до авторського розуміння навколишніх факторів і подій та свого усвідомлення конкретних дій. Таким чином, наративний художній простір являе собою своєрідне родовище реалізації маніпулятивних технологій. По-перше, це пояснюється розумінням маніпулятивних технологій як елементів зовнішнього впливу [1, с. 61]. У випадку творення наративного художнього простору зовнішнім елементом виступає наратор, що представляе історію відповідно до свого ментального 
простору. Окрім цього, ще одним зовнішнім фактором можна вважати будову романів, яка відіграє особливу роль у творенні та структуруванні наративного простору і водночас упливає на читача у відповідному напрямі, формуючи образи, картинки або історію загалом.

Аналіз останніх досліджень і публікацій. Сучасні вивчення наратологічного простору означені міждисциплінарним підходом. Наратологічні вчення проникають й в інші наукові парадигми, як-то: психологія, соціологія, гендерна лінгвістика, мистецтво тощо. Характерними ознаками робіт сучасних наратологів виявляються різноманітні структури та схеми відтворення наративного простору в різних типах текстів. Так, вивчено темпорально-оповідну структуру англомовних художніх текстів детективної прози (Л. В. Дученко); на матеріалі японської та української прози XX ст. розглянуто основні жанрові ознаки его-белетристики (Ю. В. Осадча); описано французьку готичну новелу як наративний текст особливого типу зі стійкою ускладненою композиційною структурою, яка зумовлюється домінантною роллю категорії художньої події (А. Ю. Рудковська); звертається увага дослідників на паратекстуальні особливості художнього простору, зокрема біографічної прози (Т. Ю. Черкашина); проведено дослідження жанрової палітри турецького постмодерністського роману (сімейна хроніка, детективний, інтелектуальний, фантастичний, готичний, жіночий роман з яскраво вираженою феміністичною змістовою домінантою), його стильових моделей, наративної технології, особливостей інтертекстуальності (Г. В. Рог).

3 боку структурних складників художнього твору особлива увага дослідників скерована на композиційну будову тексту. Праці сучасних мовознавців дедалі частіше спрямовані на виявлення специфіки оформлення художніх текстів (Л. Г. Бабенко, М. П. Брандес, Е. М. Зайцева, В. А. Кухаренко та інші), вчені схильні до думки, що романістичний простір охарактеризовано структурно-семантичною неоднорідністю.

Як доводять сучасні дослідження, реалізації маніпуляції сприяють особливості мовних і мовленнєвих засобів, 3-поміж яких визначено емоційно забарвлені лексичні одиниці (О.В.Дмитрук, О. А. Лагодзінська, Л. В. Мосієвич), метафори (А. А. Данилова, I. Карапетьян, Дж. Розіна), пресупозиції та імплікації (Е. В. Срмакова, С. К. Романюк, С. Топачевський, І. Ю. Шкіцька), викривлення/приховування інформації (Г. А. Копніна, І. В. Рибак, Н. С. Тарасова), різноманітні маніпулятивні стратегії і тактики (О. В. Дмитрук, А. В. Радюк, О. В. Оленюк) тощо. У нашому дослідженні намагатимемося довести, що, окрім мовних засобів, у художньому наративі особливої уваги набуває композиція, яка не лише структурує твір, а й виконує маніпулятивну функцію.

Постановка завдання. За мету в запропонованій роботі ставимо визначити та описати маніпулятивні характеристики композиційної будови художнього наративу сучасного французького письменника Марка Леві, грунтуючись текстовим простором роману «Vous revoir». Задля досягнення поставленої мети необхідно вирішити такі завдання:

- визначити наративний простір творчості французького письменника Марка Леві;

- описати основні композиційні складники твору М. Леві «Vous revoir»;

- охарактеризувати маніпулятивні функції кожного з елементів архітектоніки, що присутні в романі французького письменника;

- узагальнити результати проведеного аналізу та сформулювати перспективи подальших розвідок цієї теми.

Виклад основного матеріалу. Аналізуючи творчий доробок сучасного французького письменника Марка Леві, ми виявили, що літератор прагне до наративної форми гетеродієгетичного типу в екстрадієгетичній ситуації. Тобто в досліджуваних романах письменника наратор, що розповідає історії, знаходиться поза межами оповіді, а фокус зосереджується на головних персонажах відповідних подій. Матеріалом цієї роботи слугував роман М. Леві «Vous revoir» (2008). Мотивацією звернення до художньої творчості цього автора слугувало: по-перше, його неодмінна популярність на світовій літературній ниві; по-друге, несподівані сюжетні сплетіння в його романах; i, нарешті, власне позиціонування М. Леві не як письменника, а оповідача, розповідача своїх істоpiй. Усе, що описано французьким автором у його багаточисельних творах, відтворено таким чином, аби читач мав змогу яскраво уявити події та персонажів [3], що, на нашу думку, і має саме маніпулятивний характер, оскільки призводить до неусвідомленого збудження зацікавленості. Зокрема, цьому сприяє композиційна будова романів митця.

Виникнення сюжетів французький письменник пояснюе зовнішніми загальними умовами, що сприяють появі нових оповідань - зима, тиша, ніч [3]. Як визнає М. Леві, влітку він придумує сюжети, надихається, гуляє, а ось взимку - самий час їх описати. Сама природа, на думку письменника, сприяє усамітненню, відволіктися від 
зовнішнього - й працювати. Нараторську позицію французького автора відтворено в композиційній будові його романів, зокрема у творі «Vous revoir». Цей роман $є$ продовженням минулої істоpiï «Et si c'était vrai» (2000), проте дещо змінюються актанти наративу. Марк Леві наголошував на тому, що цікаво було би дізнатися, чи ризикнули б Артур та Лорен вдруге зустрітися та вскочити у вирій пригод [3]. Тому в аналізованому творі французького письменника «Vous revoir» зустрічаються ті ж самі персонажі, проте в дзеркальній ситуації [2, с. 46].

Щодо наративної тектоніки аналізованого твору, то змінюється дещо композиція. На відміну від попереднього роману, в якому загалом було лише дві глави, що розподілялися дейектиками сезонної приналежності Eté 1996 (M. L. :SCEV, p. 2), Hiver 1996 (M. L. :SCEV, p. 18), у романі «Vous revoir» спостерігаємо чіткий розподіл подій на глави $(1,2, \ldots)$ та окремі думки $(*)$, що складають та відтворюють композитність цих глав. Таку наративну структуру представлення подій можна пояснити саме гендерною ідентифікацією, оскільки головним оповідачем частіше виступає Лорен, представниця жіноцтва, що схильна до деталізації, послідовності розгортання хронотопу, а також маніпулятивною функцією, коли наратор 3 метою впливу наголошує на окремих елементах, подіях/діях.

Оскільки йдеться про дилогію Марка Леві «Еt si c'était vrai» i «Vous revoir», то наративний простір вибудовано таким чином, аби поєднати дві історії. Якщо звернемося до кінця попереднього дієгезису, то оповідач - Артур повернувся до справ у Францію («Et si c’était vrai»). Отже, другий роман дилогії французького письменника розпочинається саме подорожами головних героїв Артура і Лорен:

1.

Le ciel de la baie de San Francisco était rouge flamboyant. Au travers du hublot, le Golden Gate émergeait d'un nuage de brume. L'appareil s'inclina à la verticale de Tiburon, il perdit lentement de l'altitude, cap au sud, et vira à nouveau en survolant le San Mateo Bridge. Depuis l'intérieur de la cabine, on avait l'impression qu'il allait se laisser glisser ainsi vers les marais salants qui luisaient de mille éclats.

*

Le cabriolet Saab se faufila entre deux camions, coupa $[\ldots]$ (M. L. :VR, p. 3).

Глава розпочинається поверненням Артура до Сан-Франциско, де відбувалися події попередньої історії. Автор ретельно вимальовує маршрут героя, вказує всі головні пам'ятки американського міста-le Golden Gate (міст Золоті Ворота), Tiburon (острів Тібурон), le San Mateo Bridge (міст СенМетео-Хейворд), що на маніпулятивному рівні вибудовує реальність подій, надає змогу поринути у простір не лише твору, а й реальної подорожі до Сан-Франциско. Аби поєднати нараторів при незміненій фокалізації, М. Леві звертається до досить незвичного прийому, коли зберігається композитність, при цьому змінюються актанти. У романі «Vous revoir» спостерігаємо таку характерну композицію - поєднання глав та підглав. При цьому в художньому наративі французького письменника присутні дейектики, що поєднують дієгезис та створюють безперервність подій, що відбуваються. У наведеному фрагменті роману Марка Леві такими маніпулятивними елементами $\epsilon$ транспортні засоби, а саме розміщення головних героїв у межах цих засобів: Артура - у салоні літака (l'intérieur de la cabine), Лорен - у машині (Le cabriolet Saab).

Такий наративний прийом чергування та зміни актантів має маніпулятивну функцію не лише переходу від однієї історії до іншої, зміни фокалізаторів, а й набуває ефекту «нанизування» подій.

[...] - Accélère, on va rater le coucher de soleil !

- Nous avons deux heures d'avance et depuis quand as-tu l'âme bucolique?

- Mais je m'en fiche du crépuscule! Ce qui m'intéresse ce sont les filles sur la plage!

Le soleil déclinait déjà et ses rayons filtraient entre les étagères d'une petite bibliothèque qui occultait la fenêtre à l'angle du salon. Lauren avait dormi une bonne partie de l'après-midi. Elle regarda sa montre et se rendit dans la salle de bains. Elle se rafraîchit le visage sous l'eau, ouvrit le placard et hésita devant un pantalon de jogging. Elle avait à peine le temps d'aller courir à la Marina si elle voulait reprendre son service de nuit à l'heure, mais elle avait besoin de s'aérer (M. L. :VR, p. 17).

У наведеному прикладі спостерігаємо дві події різних героїв - прогулянка друзів (Артура і Поля) на пляж та пробіжка Лорен перед початком чергування у шпиталі. Основними дейектиками, що поєднують дієгезиси, $є$ вказівка на час суток (захід сонця le coucher de soleil, Le soleil déclinait déjà) та просторові маркери (sur la plage, à la Marina). Наратор використовує такий маніпулятивний прийом не лише задля поєднання двох хронотопів, а й з метою зображення двоїстості подій, що відбуваються. Несвідомо здається, що герої роману М. Леві осьось мають перетнутися, зустрітися, поєднатися. 
Наративний простір аналізованого твору Марка Леві характеризовано структурою «нанизування» подій та зміни фокалізації, що відображено завдяки композиції:

La lumière d'un lampadaire qui vacillait dans la rue déserte s'éteignit. Le petit matin au ciel pâle venait de se lever.

Arthur s'était assoupi sur la balancelle. Le jour naissant enveloppait les lieux de douceur. Il ouvrit les yeux et regarda la maison qui semblait dormir, paisible. En contrebas l'océan léchait le sable, achevant son ouvrage de la nuit. La plage avait retrouvé son habit lisse, immaculé. Il se releva et inspira profondément l'odeur du matin frais (M. L. :VR, p. 34).

Розподіл глав на різноманітні підглави має маніпулятивну функцію. Спостерігається перегукування дієгезиса зі змінними фокалізаторами. Так, у наведеному фрагменті події, пов'язані 3 головною героїнею, закінчуються світанком, що на семантичному рівні імпліцитно виражено дейектиками: La lumière d'un lampadaire ... s'éteignit (світло ліхтаря згасало - тут і далі переклад наш - Ж.Б.), Le petit matin - «tout début de la journée» [лярус] (світанок). А наступна частина глави оповідає про Артура, хоча основними маркерами цього наративу також $\epsilon$ семантика нового дня, світанку: Le jour naissant, achevant son ouvrage de la nuit, inspira l'odeur du matin frais. Такий прийом набуває ефекту безперервності представлення подій.

У наступному фрагменті наративного простору французького письменника також привертає увагу його тектоніка. Лорен мріяла подивитися ще раз фільм «Він і вона» з Гарі Грантом та Деборой Керр у головних ролях. Проте, згадавши про важкий день, який чекав на неї наступного дня, вона передумала і не зупинилася біля магазину відеокасет:

Elle rêvait de revoir Cary Grant et Deborah Kerr dans Elle et lui, et puis repensant à sa matinée du lendemain, elle enclencha la seconde et accéléra en passant devant une vieille Ford 1961 qui était garée devant le vidéoclub.

Arthur étudiait un à un les titres de la section «Arts martiaux (M.L. :VR, p. 41).

$\mathrm{У}$ той самий час Артур також вибирав, чим себе розважити у вільний час. Така наративна тектоніка не лише поєднує оповіді та зберігає постійно хронотоп, що надає наративу ефекту безкінечності.

Особливістю архітектоніки творів Марка Леві $\epsilon$ нанизування подій у різних проявах дієгезису, що створює ефект безперервності, одночасності хронотопу. Існує впродовж усієї оповіді зв'язок закінчення попередньої глави та початку наступної:

Lauren le quitta au bout de la jetée, il la regarda $s$ 'éloigner sans rien dire. Certains moments ont un goût d'éternité.

15.

Il l'attendait au pied du grand pont, assis sur un muret en brique. A cet endroit, les vagues de l'océan affrontaient celles de la baie, dans un combat qui durait depuis la nuit des temps (M.L. :VR, p. 194).

Попередня історія закінчується на березі океану, коли Лорен попрощалася з Артуром та пішла. Особливого значення набуває сема jetée n.f - «Ouvrage enraciné dans le rivage et établi en vue de permettre l'accès d'une installation portuaire située au large, de faciliter les manœuvres des bateaux et navires dans les chenaux d'accès à un port» [5], яка імплікує поєднання двох стихій - Землі та Води. Такі різні персонажі (Лорен і Артур), як із боку гендерної належності, так й $з$ особистісних характеристик, поєднані в площині одного наративного простору. Крім цього, образ води імплікує очищення, зміни та вічності, що на психологічному рівні направляе читача до роздумів про вічні питання, тобто маніпулює нашим сприйняттям відповідного дієгезису. Зважаючи на те, що йдеться про кінцівку глави роману французького письменника, наратор наполягає на метафоричності подій та обставин, на що вказує така фраза - Certains moments ont un goût d'éternité (Деякі моменти мають присмак вічності). Така незакінчена кінцівка має маніпулятивний ефект, що змушує читача не лише до роздумів, а й тримає наратив у постійному тонусі.

Наративний простір досліджуваного твору постійно перебуває у зв'язку з дієгезисом, про що свідчить так зване «нанизування» подій оповіді. Отже, на початку наступної глави роману «Vous revoir» спостерігаємо збереження місця події, що на вербальному рівні підтверджено місцезнаходженням Артура біля мосту (Il l'attendait au pied du grand pont). Окрім цього, наратор продовжує роздуми щодо вічності буття. Імплицитно це виражено знову метафорою - les vagues de l'océan affrontaient celles de la baie, dans un combat qui durait depuis la nuit des temps. Ha прикладі боротьби вод океану та заливу, що стикаються, перебуваючи весь час у боротьбі, герої аналізованого твору перебувають постійно також у боротьбі із зовнішніми чинниками, що заважають їм зустрітися. Таким чином, автор увесь час тримає читача в напрузі, впливає на його почуття, відчуття та сприйняття. 
Марк Леві у творі «Vous revoir» весь час намагається вказати на поєднання двох романів. У художньому наративі досліджуваного простору спостерігаємо такий натяк не лише в його тектоніці, а й на рівні знаків, образів:

Lauren remercia le gardien d'un sourire, la barrière se leva et elle appuya aussitôt sur l'accélérateur ; nouveau crissement de pneus. Le vent souleva quelques mèches de ses cheveux, découvrant sur le front la cicatrice d'une ancienne blessure (M. L. :VR, p. 9). У наведеному прикладі 3 маніпулятивною метою автор використовує лексему cicatrice n., f. «trace physique ou morale laissée par les malheurs, les souffrances» [5], що імпліцитно вказує на попередню історію, коли Лорен була в комі.

I все ж таки Марк Леві вибудовує композицію своїх творів відповідно до загальних традицій, за якими існують усі складники - від епіграфу до епілогу. Так, у досліджуваному романі французького письменника спостерігаємо наявність саме таких позицій у композиційній тектоніці. Аби узагальнити події, М. Леві звертається до епілогу: Épilogue (M. L. :VR, p. 257), в якому розповідається про долі всіх персонажів твору. Проте, що стосується головних героїв роману «Vous revoir»: Quant à Arthur et Lauren, ils ont demandé à ce qu'on ne les dérange pas...

\section{Pendant quelque temps...}

FIN (M. L. :VR, p. 258), то автор умисно не звертається до деталей їхнього подальшого життя, а лише натякає - ils ont demandé à ce qu'on ne les dérange pas (вони просили, аби їх не турбували). Синтаксичний знак - три крапки - вказує на незакінченість історії, натякає на її продовження та має маніпулятивну функцію, оскільки дещо змінює вже сформовану у свідомості читача кінцівку щасливого завершення любовної історії. Проте автор натякає на неповну завершеність, що на вербальному рівні зображено - Pendant quelque temps. Тобто деякий час варто не звертатися до цих персонажів. Хоча завершується оповідь експліцитним позначенням - FIN.

Висновки і пропозиції. Таким чином, проведений аналіз роману Марка Леві «Vous revoir» надає підстави вважати, що композиційна будова твору не лише структурує наративний простір, а й набуває маніпулятивного потенціалу, оскільки спрямовує читача на розуміння подій у тому чи іншому ракурсі, цікавить, змушує дізнатися кінець історії. Перспективним у подальших пошуках вважаємо звернутися до гендерної диференціації наративних типів та простежити композиційні особливості французького наративного простору 3 боку прояву його маніпулятивного потенціалу.

\section{Список літератури:}

1. Буць Ж. В. Сутність поняття «маніпулятивні технології» у мовознавчій парадигмі. Актуальні проблеми романо-германської філології та прикладної лінгвістики: науковий журнал. Чернівці : Чернівецький національний університет імені Юрія Федьковича, 2019. Вип. 1 (17). С. $60-69$.

2. Мацевко-Бекерська Л. Наратив містичного у прозі Марка Леві. Питання літературознавства. Чернівці : Чернівецький національний університет, 2011. Вип.84. С. 46-54.

3. Французский писатель - Марк Леви: Биография. URL: https://sites.google.com/site/marklevilnv/ (дата звернення: 09.12.2019).

4. Buts Zh.V. The conception of "manipulation" in the humanitarian paradigm (the problem of terminologization). The European Journal of Humanities and Social Sciences: Scientific journal. Vienna : Premier Publishing, 2019. № 4. P. 36-39. URL: http://ppublishing.org/ru/archive/journals/769

5. Larousse : dictionnaire de français. URL: https://www.larousse.fr/dictionnaires (дата звернення: 04.03.2019).

\section{Джерела ілюстративного матеріалу:}

M. L. :SCEV Levy M. Et si c'était vrai. Édition Robert Laffont, S.A., Paris 2000. 211 p. ISBN 2-266-10453-5

M. L. :VR Levy M. Vous revoir. Édition Robert Laffont, S.A., Paris 2005. 258 p.

\section{Buts Zh. V. THE MANIPULATIVE POTENTIAL OF THE COMPOSITIONAL STRUCTURE OF M. LEVY'S NARRATIVE (ON THE EXAMPLE OF THE NOVEL «VOUS REVOIR»)}

This article analyzes the narrative space of the novel of the modern French writer M. Levy "Vous revoir". Particularly, special attention is paid to the composition's structure of this novel and to the determination of its manipulative potential. Based on the ideas of modern linguists, the author tries to combine different concepts of linguistics. At first, the author of this text provides an explanation of the manipulation. Beside she justifies the combination of several linguistic paradigms in one study.

The proposed work describes the main courses of the narratives studies. According to the ideas of modern scientists in the narratology there were formulated and explained the realization of manipulation in the novel's 
space of contemporary French romance by linguistic and speech means. In order to understand the manipulative influence realized in the narrative space of this French writer, our attention is focused on his narrative manner. It has been proved that M. Levy aspires for the narration as the heterodiegetic type in the extradiegetic situation. That is, in these tales, the narrator who tells the story is beyond its, and the attention is focused on the main characters of the events.

Particular attention of the article's author is extended on the structure of the composition of Mark Levy's novel "Vous revoir". It is outlined the basics components of its composition, as well its manipulative functions are characterized. As a result it has demonstrated that the composition of this novel not only structures the narrative space, but also it acquires a manipulative potential, because the composition's structure directs the reader to understand the events in main perspectives, makes him interested, forces him find out the end of the story.

As a summary of this article we had outlined the prospects for further searches on this topic. Therefore, we consider to address to the gender differentiation of narrative types.

Key words: narrative, composition, manipulation, manipulative influence, manipulative potential, story. 